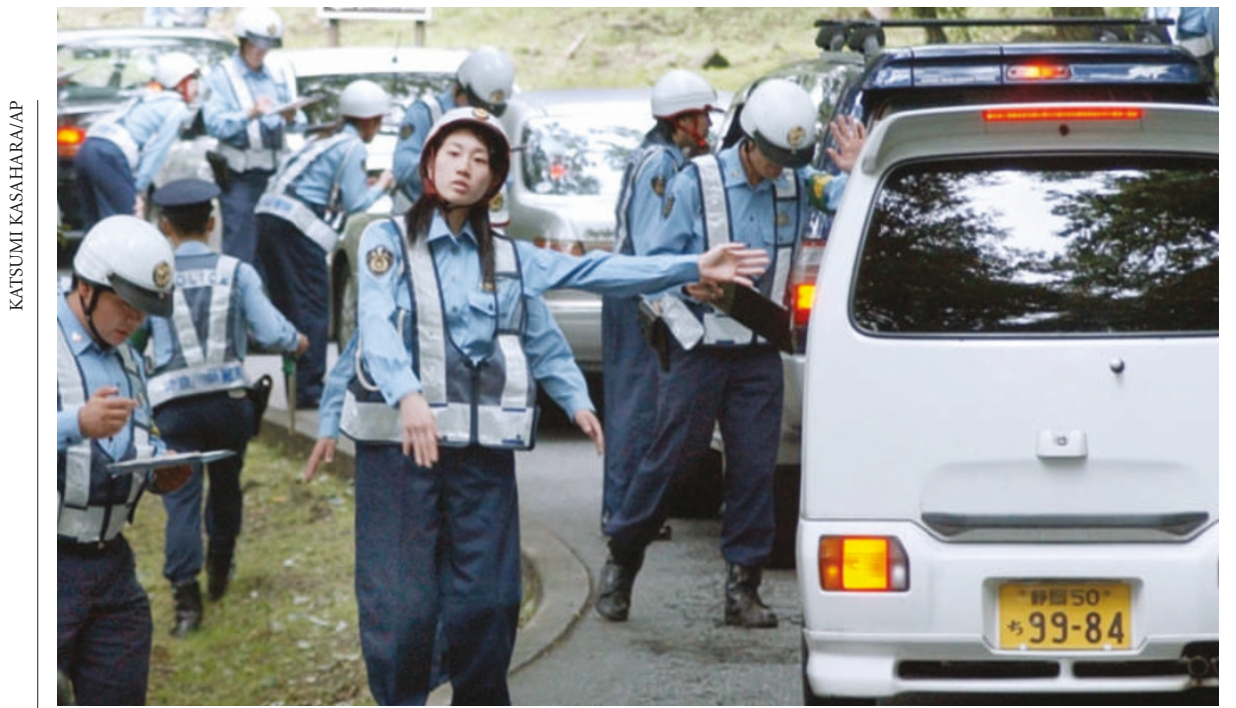

Trial and error: Japanese police want to link biological evidence to a perpetrator's ethnic background.

\title{
Japan's ethnic crime database sparks fears over human rights
}

David Cyranoski, Tokyo

Ethnic profiles derived from biological material at crime scenes are set to become an integral part of criminal investigations in Japan.

The move has provoked criticism from scientists and human-rights activists who fear that the data will be used to target foreigners unfairly.

In a four-year, ¥153-million (US\$1.4million) project, forensic scientists at the National Research Institute of Police Science in Tsukuba, north of Tokyo, plan to set up a database that will allow police to get clues about a suspect's ethnic origin and physical appearance.

The Japanese authorities cite the increase in crimes committed by foreigners as justification for the project. Together with research into identifying the origin of falsified passports, the ethnicity indicators will "help in the investigation of crimes involving foreigners, and by leading to a quick resolution of these crimes, effectively reduce their number and decrease social unrest", according to the initiative's outline.

But Makoto Teranaka, head of Amnesty International's Tokyo office, describes the project as a "sign of a moral panic", adding that it compounds Amnesty's long-standing concerns about how Japan's prosecution system attains its stunningly high conviction rate of about 99\%."We want Japan to bring its system up to international standards for fair trial and interrogation," he says.

The database will gather data on ethnicity, blood type, metabolic enzymes, hair and skin pigment proteins, mitochondrial DNA and signs of asymptomatic viral infections that can be used to distinguish ethnicities.

There is nothing new about using biological features, as in DNA profiling, to identify criminals, but ethnicity data are usually only used in the identification of badly damaged corpses. The Japanese initiative is thought to be the first that will try to attach an ethnic profile to an individual's DNA.

A number of Japanese researchers share Amnesty's concern about the project, although they declined to criticize it openly. One prominent geneticist at a leading Japanese university, contacted by Nature, dismissed the plan as "stupid" but refused to comment on it publicly.

And Japanese forensic scientists, whose research is being redirected from corpse identification for the project, are worried. "It gets a little difficult ethically," says one, who didn't want to be identified. "We have to worry about human rights, especially when the tests have some uncertainty built into them." But the researcher also agrees with the authorities that growing crime by foreigners might justify the initiative.

Scientists at the police-science institute insist that the tools will "only be used to narrow in on foreign criminals or victims and not to discriminate against individuals or ethnicities". But critics charge that the initiative fits in with a pattern of actions that scapegoat foreigners for Japan's social and economic problems.

Koichi Hamai, a criminologist at Ryukoku University in Kyoto who worked at the justice ministry for 19 years, worries that the initiative might encourage the police to focus on foreigners. "It could become a dangerous prejudice," he says. The number of foreigners convicted of murder - 41 in 2003 is actually decreasing, Hamai adds, and theft convictions, although increasing, amounted to only 280 cases out of 4,151. "Foreigners have become a scapegoat in the years since the bubble economy burst," he says.
North Korea offers US tour party glimpse of weapons programme

Geoff Brumfiel, Washington

Speeding along a deserted highway towards North Korea's secret city of Yongbyon earlier this month, Siegfried Hecker, former director of the Los Alamos nuclear-weapons laboratory in New Mexico, wasn't sure what to expect.

"I had heard that the North Koreans were less than cooperative, to put it kindly," he says. In the end, Hecker, who was invited to make the semi-official trip by North Korea's nuclear-weapons researchers, came away impressed by their technical expertise, but unsure of the status of their weapons programme.

Hecker, who told a closed Senate hearing on 21 January about his visit and later discussed it with reporters, says he engaged in a surprisingly frank and even humorous discussion with his North Korean counterparts. Ri Hong Sop, the director of the Yongbyon facility, gave Hecker and four other US visitors a guided tour on 8 January and sought to convince them that North Korea had successfully assembled nuclear weapons.

The visitors were shown a cooling pond where 8,000 spent fuel rods had been housed in steel canisters. The North Koreans claimed that all of them had been reprocessed to extract plutonium, but many of the canisters looked to be intact. "I said, 'I can't go back home and report that all the fuel rods are missing, because I didn't see them all empty', "Hecker recalls. So Sop suggested that he test the claim by choosing a canister to be opened at random. When he opened a random canister and found it empty, he concluded that the fuel rods were indeed missing.

Later, Hecker was allowed to handle a mildly warm metal sample, which the North Koreans claimed was bomb-grade plutonium alloy. Hecker, a metallurgist who knows plutonium and its alloys rather well, asked Sop what he had used to create the alloy. "He said, 'I'm not authorized to tell you, but you know, it's the same stuff that you use." Hecker says he is reasonably convinced that what he held could have been weapons-grade plutonium.

But Hecker is less sure that North Korea has turned its plutonium into a bomb. A plutonium-based weapon is more difficult to build than the enricheduranium device that some analysts assumed North Korea would try to build. But Hecker was impressed by the technical abilities of some of the scientists he met. "The people were very competent, no question about it," he says. 